\title{
Experimental Study of Improving the Properties of Lime-Stabilized Structural Lateritic Soil for Highway Structural Works using Groundnut Shell Ash
}

\author{
Olugbenga AMU ${ }^{1}$, Oluwaseun ADETAYO ${ }^{1, *}$, \\ Feyidamilola FALUYI ${ }^{1}$ and Emmanuel AKINYELE ${ }^{2}$ \\ ${ }^{1}$ Department of Civil Engineering, Faculty of Engineering, Federal University Oye Ekiti, Nigeria \\ ${ }^{2}$ Department of Civil Engineering, Faculty of Engineering, Obafemi Awolowo University, Ile-Ife, Nigeria
}

("Corresponding author's e-mail: oluwaseun.adetayo@fuoye.edu.ng)

Received: 3 February 2020, Revised: 24 July 2020, Accepted: 25 August 2020

\begin{abstract}
This research considered the viability of groundnut shell ash (GSA) on lime-stabilized lateritic soil for highway structural works. Three samples of lateritic soil, named samples A, B, and C, were gathered from Idita-Mokuro, NTA-Mokuro, and ETF burrow pits, respectively, in Ile-Ife, Osun State, Nigeria. Preliminary tests were completed on the samples in their natural states and when stabilized with optimum lime. Engineering properties were performed while 2, 4, and $6 \%$ GSA contents were added to the soil samples at optimum lime. The Atterberg limit tests showed a significant reduction in the plasticity index for samples $\mathrm{A}$ and $\mathrm{C}$ when stabilized with lime. Compaction test showed a decrease in the maximum dry density from 1,685 to $1,590 \mathrm{~kg} / \mathrm{m}^{3}$ for sample A, 1,599 to $1,512 \mathrm{~kg} / \mathrm{m}^{3}$ for sample $\mathrm{B}$, and 1,396 to 1,270 $\mathrm{kg} / \mathrm{m}^{3}$ for sample $\mathrm{C}$ on stabilizing with lime; the introduction of GSA to stabilized lime soil diminished the maximum dry density for all the soil samples, with sample A reduced to 1,435 and $1,385 \mathrm{~kg} / \mathrm{m}^{3}$ at 2 and 4 GSA contents, respectively. The addition of GSA improved the engineering properties of limestabilized soils as the unsoaked CBR esteems expanded for all soil samples. At an optimum lime dosage, the addition of $2 \%$ GSA expanded the triaxial shear strength from 60.43 to $188.36 \mathrm{kN} / \mathrm{m}^{2}$ for sample A and, at $4 \%$ GSA content, both soil samples B and C increased from 19.19 to $201.48 \mathrm{kN} / \mathrm{m}^{2}$ and 30.62 to $111.65 \mathrm{kN} / \mathrm{m}^{2}$, respectively. Conclusively, GSA improved the toughness and strength of lime-stabilized lateritic soil for highway structural works.
\end{abstract}

Keywords: Laterite soil stabilization, Optimum lime, Groundnut shell ash, Highway structural works

\section{Introduction}

When getting ready for blended and basic plans for roadway structural works, there are 3 basic outer structure parameters to consider: the attributes of the subgrade whereupon the foundations are put, the applied loads on the foundation, and the earth. To start with, the subgrade whereupon the pavement structure is put will have a large impact on the response of the pavement structure [1]. Subgrade firmness and seepage characteristics help decide the foundation layer thickness, the number of layers, seasonal load restrictions, and any potential upgrades to subgrade stiffness and drainage itself [2]. Second, the expected traffic loading on the pavement is of essential primary design input in both mixed design and structural design [3]. Cement and lime are the 2 basic materials utilized for stabilizing soils; however, these materials have quickly expanded in cost in because of a sharp increase in the cost of energy since the 1970s [4]. The over-reliance on the use of mechanically-made soil-improving added substances (cement, lime, and others) has kept the expense of structural engineering projects extremely high. This, until now, 
http://wjst.wu.ac.th

has kept on discouraging the developing, underdeveloped, and poor countries of the world from giving generally standard structures to dwellers that comprise the higher levels of their populaces [5]. The mission to find materials that can fill in as a replacement for cement in soil foundation add up to an advantageous exertion. A few examinations have been made on soil stabilization utilizing distinctive stabilizing agents. Sharo et al. [6] demonstrated the adequacy of the expansion of calcium chloride in soil treatment. Amhadi and Assaf [7] utilized calcium oxide as a stabilization technique in clay soils so as to restrain its development contraction properties. Hesami et al. [8] utilized coal burning results in rollercompacted solid, roadway, and parking areas. Elbaz et al. [9] and Norhaiza et al. [10] explored the impact of fly ash and pozzolanic material on soil improvement. This investigation was centered around the capability of GSA as an addictive substance on cement-stabilized lateritic soil for sustainable highway structural works to the point of finding an appropriate supplement for cement in soil stabilization.

Groundnut shell is an agrarian waste acquired from the processing of groundnut. Nigeria contributes around $7 \%$ of the world groundnut generation, which makes Nigeria the $3^{\text {rd }}$ biggest producer of groundnut on the planet [11]. In 2002, around 2,699,000 metric tons of groundnut were created in around $2,783,000$ hectares of land. Out of the few million tons of groundnut delivered to the planet every year, hulls/shell represents around $25 \%$ of the total mass created and is basically used in cattle and poultry feed. Groundnut shell has incredible potential for business use. It is utilized as a fuel, a filler in cow feed, as hard particle board, stopper substitute, activated carbon, and so forth. The hull/shell is significant as livestock fodder, especially in dry season in the semi-arid tropics.

When relatively little amounts of lime are added to granular soil or sediment mud (silt-clay) soil, the chemical and physical properties of that soil are changed [12]. It is a condition for the ensuing pozzolanic responses, in which lime decreases the pliancy and water-holding limit of the soil and builds its bearing capacities. The level of progress relies on the amount of lime utilized and the nature of the soil. In limealtered soil, just enough lime is utilized to change the physical properties of the soil to the degree wanted. Knowing that GSA, a derivative of groundnut shell, being a waste, has presently no value, and also constitutes an environmental nuisance, will its presence enhance the pozzolanic activities of lateritic soil, and thus become a viable material? What will be the impacts of GSA on lime-stabilized lateritic soil for highway structural works, in relation to the sustenance condition for pozzolanic response for improved Geotechnical properties? This is the fundamental research question in this investigation.

\section{Subgrade failure}

Structural works fail because of numerous reasons; components which incorporate poor construction, poor design, or poor materials are a portion of the essential causes. 1 significant reason for failure lies in the subgrade part. The subgrade layer, which speaks to the foundation bedrock, is of key significance in the foundation. How solid, firm, and immersed this layer is will control the general structural foundation execution. The principle capacity of subgrade soils is as support for structural foundations. Under substantial superstructures, subgrade soils may twist and add to trouble in the structural pavement. Subgrade soils, specifically, feeble delicate subgrades, contribute a critical part (above $40 \%$ ) of the complete plastic deformation of a pavement layer at the center of an applied load [13]. In this way, unreasonable plastic deformation at the highest point of a subgrade layer may lead to the falling apart of the structural foundation through rutting or splitting. When subgrade soil is saturated, cohesive soils (fine-grained) can hold water in their voids because of the extremely low permeability. This pore water has 3 negative consequences for fine-grained soils [14]:

- high water contents in cohesive soils cause a lubrication effect at the soil particle contact points, subsequently expanding the plastic deformation in wet soils under constant deviatoric stacking,

- strengths of wet (immersed) soils is lower and, hence, ceaseless stacking incites more harm to subgrade soils, and

- positive pore pressures in close-to-soaked conditions increase with the quantity of burden applications and, thus, bring about softening, so the probability of harm occurring from heavy traffic loads increase drastically. 
http://wjst.wu.ac.th

Hence, saturated subgrade layers lose support from the subgrade and base layers in view of the loss of strength in these layers. A subgrade layer that has no help beneath it will rapidly decay.

\section{Lateritic soil}

The most widely recognized materials utilized for Civil Engineering constructions are lateritic soils since they occur naturally with intense weathering and lack of good quality crushed aggregates as well as economically attractive. Laterite is a profoundly durable material, wealthy in secondary oxides of iron, aluminum, or both. Laterites are reddish-brown, very much graded, and sometimes extend to depth of several tens of meters. They are found in tropical and subtropical regions with wide applications in the construction industries [15]. There are 2 sorts: fine laterite, and rock or quarry laterite. For engineering purposes, Oyelami and Rooy [16] has recognized 2 sorts of fine laterites: "sensitive" and "stable" laterites. Sensitive laterite, which is unsatisfactory for engineering purposes, is commonly found in regions of recent volcanic movement, and assessment of its properties is untrustworthy. Steady laterite, which is reasonable for structural works, is manageable in standard laboratory tests. The investigation of the attributes of laterite is significant in the regions of consistency limits, grain size distribution, permeability compaction, and consolidation, and the shear strength of lateritic soil is significant, particularly the connection between its plasticity (consistency limits) and compressibility attributes, as it influences its utilization as a construction material. Ogbuagu and Okeke [17] uncovered that lateritic soils are hole-evaluated with insufficiency in sand and residue size particles. Lateritic soils, for example, expansive soils, are typically experienced in foundation engineering, structural designs for roadways, dikes, retaining walls, refills, and so forth. Expansive soils are typically found in semi-dry regions of tropical and calm atmosphere zones, and are copious, where the yearly dissipation surpasses precipitation and can be found anyplace on the planet $[18,19]$. Laterite generally contains a decent amount of clay particles. Clays display commonly undesirable engineering properties. They will, in general, have low shear strength. and lose shear strength further after wetting or other physically unsettling influences [20]. They can be plastic and compressible, and they expand when wetted and recoil when dried. Some sorts expand and recoil incredibly after wetting and drying- a truly unwanted component. Cohesive soils can crawl after some time under a steady burden, particularly when the shear stress moves toward the shear strength, making them inclined to sliding. They grow enormous horizontal weights. They will, in general, have low plastic modulus values [21]. Therefore, clays are commonly poor materials for structural foundation works [22]. Lateritic soil normally fills in as the formation level in roadway structural projects, thus the requirement for sufficient strength to help the overlying strata. This existing soil, for the most part, comprises extensive mud, which has an extremely poor bearing capacity $(\mathrm{CBR}<1 \%)$ and has high swelling potential (PI > 20). Typical properties of normal lateritic soil are shown in Table 1.

Table 1 Typical properties of a sample of lateritic soil (Soil stabilization with fly ash and rice husk ash) [23].

\begin{tabular}{cc}
\hline Properties & Soil \\
\hline Specific Gravity & 2.64 \\
\% Passing \#200 Sieve & $40 \%$ \\
Liquid Limit & 45 \\
Plastic Limit & 24 \\
Plasticity Index & 21 \\
Free Swell Index & $17 \%$ \\
USCS Classification & $\mathrm{CH}$ \\
\hline
\end{tabular}




\section{Groundnut shell ash}

Groundnut pods have an thick outer woody shell with 2 or 3 seeds embedded inside. The shelling percentage ranges from 60 to $75 \%$ [24]. The seed consists of 2 cotyledons, germ, and thin skin called testa. The testa is composed of carbohydrates, cellulose, protein, and phenolic compounds, while cotyledons have mainly oil and protein. The germ contains a high proportion of protein, reducing sugar, and disaccharides. The quality, characteristics, and uses of groundnut vary among developed and developing countries. In developed countries, groundnut is used for the preparation of peanut butter and confectionery products. In developing countries, it is mainly used for oil extraction, and its by-product is utilized for feed and food purposes [25]. The ash obtained by burning the groundnut shells is named groundnut shell ash (GSA). The burnt ash is passed through a BS sieve (75 microns); the portion passing through the sieve has the required degree of fineness of $0.063 \mathrm{~mm}$ and below, while the residue is thrown away [26]. Groundnut shell ash, like ordinary Portland cement, contains calcium oxide $(\mathrm{CaO})$, but in a lower percentage than ordinary Portland cement, which makes it beneficial to both soil and concrete. In an investigation [27] to determine the potential of GSA as a concrete admixture, ash was generated by burning groundnut shells on an iron sheet in the open air under normal temperatures. The ash was then mixed in proportions with cement in concrete cube production. The proportions included 100:0 \% as control, 70:30, 60:40, 50:50, 40:60, and 30:70\%, respectively. The cubes were allowed to set under air for $24 \mathrm{~h}$ before being cured for 28 days in a clean pond of tap water. The results showed that, as the percentage ash in the ash-cement composition increased, the compressive strength decreased. At 90:10 cement/ash, the compressive strength increased by about $81.8 \%$ from a 7 to 28 days curing period. At 20 $\%$ ash, compressive strength decreased by $10 \%$, while there were increases of about $36.79,32.01$, and $55.66 \%$ recorded with 30,40 , and $50 \%$ GSA, respectively, from a 7 to 28 days curing period.

\section{Soil stabilization}

Soil stabilization essentially changes the attributes of a soil to deliver long haul perpetual quality and solidness, especially in activities of water and frost. Soil stabilization improves the shearing resistance of soil, firmness, and resistance to wear, and diminishes the measure of residue and the water entrance of unlocked roads. The 2 general strategies for stabilization are mechanical and chemical (added substance) stabilization. The viability of stabilization relies on the capacity to acquire consistency in mixing the different materials. Blending in a stationary or voyaging plant is preferred; nonetheless, different methods for blending, for example, scarifies, furrows, circles, graders, and revolving blenders, have been agreeable. The strategy for stabilization is dictated by the measure of settling required and the conditions experienced in the venture. A precise soil portrayal and grouping is fundamental to the determination of the right materials and methodology. Table 2 records the most reasonable treatments for different soil types to stabilize these soils for various objectives [28].

Table 2 Stabilization methods most suitable for specific applications [28].

\begin{tabular}{|c|c|c|c|}
\hline & Purpose & Soil Type & Method* \\
\hline \multirow{8}{*}{$\begin{array}{l}\text { Subgrade } \\
\text { stabilization }\end{array}$} & $\begin{array}{l}\text { Improved load carrying and stress distribution } \\
\text { characteristics }\end{array}$ & Clays of high PI & $\begin{array}{c}\text { SA, SC, MB, C, CMS, LMS, } \\
\text { SL }\end{array}$ \\
\hline & \multirow[t]{2}{*}{ Reduced frost susceptibility } & Fine granular & $\mathrm{CMS}, \mathrm{SA}, \mathrm{SC}, \mathrm{LF}$ \\
\hline & & Clay of low PI & CMS, SC, SL, LMS \\
\hline & Waterproofing and improved runoff & Clays of low PI & CMS, SA, LMS, SL \\
\hline & \multirow[t]{2}{*}{ Control of shrinkage and swell } & Clays of low PI & CMS, SC, C, LMS, SL \\
\hline & & Clays of high PI & $\mathrm{SL}$ \\
\hline & \multirow[t]{2}{*}{ Reduced resiliency } & Clays of high PI & Fine Granular \\
\hline & & Plastic silts or clays & Coarse granular \\
\hline
\end{tabular}


http://wjst.wu.ac.th

\begin{tabular}{llcc}
\hline & \multicolumn{1}{c}{ Purpose } & Soil Type & Method* \\
\hline \multirow{3}{*}{$\begin{array}{l}\text { Base course } \\
\text { stabilization }\end{array}$} & Improvements of substandard materials & Fine granular & Clays of low PI \\
& $\begin{array}{l}\text { Improved load carrying and stress distribution } \\
\text { characteristics }\end{array}$ & Clay of low PI & SC, SL \\
& Coarse granular & SA, SC, MB, LF \\
& Reduction of pumping & Fine granular & SC, SA, LF, MB \\
& & Fine granular & SC, SA, LF, MB, membrane \\
\hline \multirow{2}{*}{$\begin{array}{l}\text { Dust palliative } \\
\end{array}$} & Dust palliative & Fine granular & CMS, SA, Oil or bituminous \\
& & Plastic soils & CMS, SL, LMS, APSB, DCA \\
\hline
\end{tabular}

*APSB- Asphalt Penetration Surface Binder; C- Compaction; CMS- Cement Modified Soil; DCA 70Polyvinylacetate Emulsion; LF- Lime Fly Ash; LMS- Lime Modified Soil; MB- Mechanical Blending; SA- SoilAsphalt; SC- Soil Cement; SL- Soil-Lime.

\section{Effect of lime on soil characteristics}

Lime as quicklime $(\mathrm{CaO})$, hydrated lime $\left(\mathrm{Ca}[\mathrm{OH}]_{2}\right)$, or lime slurry can be utilized to treat soils. Quicklime is produced by artificially changing calcium carbonate $\left(\mathrm{CaCO}_{3}\right)$ into calcium oxide. Hydrated lime is made when quicklime artificially reacts with water. Lime stabilization is an entrenched strategy to improve the subgrade properties of various soils for highway structural works, in spite of construction troubles and its ineffectualness in specific conditions [29]. Lime, either alone or in a mix with different materials, can be utilized to treat a range of soil types. The mineralogical properties of the soils will decide their level of reactivity with lime and the ultimate strength that the stabilized layers will create. Generally, fine-grained mud soils (with at least $25 \%$ passing the \#200 sifter $(74 \mathrm{~mm}$ ) and a Plasticity Index more noteworthy than $10 \%$ ) are viewed as acceptable possibilities for stabilization. Soils containing huge measures of natural material (more noteworthy than around $1 \%$ ) or sulfates (more prominent than $0.3 \%$ ) may require extra lime and, additionally, special construction techniques [30]. Lime can permanently stabilize fine-grained soil utilized as a subgrade or subbase to make a layer with structural value in a pavement system. The rewarded soils might be in-place (subgrade) or acquire materials. Subgrade stabilization, for the most part, includes in-place and generally requires adding 3 to 6 $\%$ lime by weight of the dry soil.

By and large, all lime-treated lateritic soils show diminished plasticity, improved workability, and decreased volume change qualities. In any case, not all soils display improved strength attributes. It ought to be accentuated that the properties of soil-lime blends are subject to numerous factors. Soil type, lime type, lime rate, and relieving conditions (time, temperature, and dampness) are the most significant [31].

\section{Materials and methods}

The lateritic soil samples for the project were acquired from 3 distinctive burrow pits around Ile-Ife and its environs. These burrow pits are utilized for road construction in these regions. The locations of the burrow pits were; Idita-Mokuro Area, NTA-Mokuro and Educational Trust Fund (ETF), Obafemi Awolowo University, Ile-Ife, Osun State Nigeria. The type of lime utilized for the stabilization was hydrated lime. This was acquired by obtaining it in $25 \mathrm{~kg}$-sacks from a standard chemical store. The groundnut shell was sourced from nearby ranchers. It was washed and liberated from any earth or contaminant. The shell was then dried outdoors for $72 \mathrm{~h}$. The ash was acquired by burning the shells outdoors under normal temperatures in a steel compartment. Consumptive water was acquired from faucet water accessible in the research center. 


\section{Pre-treatment of soil samples}

The materials were satisfactorily checked for suitability and put away in cool, dry areas in the open air. The lateritic soil samples were spread in the sun to dry for about 14 days preceding tests to dispense all dampness. To guarantee total vanishing, the samples were turned over as often as possible. The hydrated lime was kept safe to forestall any contact with dampness and whatever other outside variables that could influence its property. The GSA was also contained in packs to shield it from moisture and any external influence that could affect its property.

\section{Test and method}

The research utilized the standard hardware of the Civil Engineering laboratory workshop at the Obafemi Awolowo University, Ile-Ife. The equipment used in the laboratory incorporated, but was not restricted to:

- Set of British Standard sieves

- Chemical weighing balance

- Drying Oven

- CBR machine

- Triaxial stacking device

- Standard Proctor mold

The techniques and procedures for different tests utilized in this research project were done as per both standard codes of the British Standard International codes [32] and the American Society for Testing and Materials [33].

Preliminary tests, including natural moisture content, specific gravity, particle size analysis, and Atterberg's limit, were completed on un-stabilized and stabilized soil samples to determine the index properties and the soil type. The standard test technique for liquid limit, plastic limit, and plasticity index of soils was finished following procedures by [34]. The test was completed on the natural soil without the option of the additive (lime and GSA) to discover, as far as possible, the liquid limit, plastic limit, and plasticity index of the natural soil samples; this empowered the simplicity of watching the impact of the additive on the natural soil when included and tested. The addition of the additive was as per the following;

- Lime dosage (4, 6, 8, and $10 \%$ by soil weight)

- Groundnut shell ash in shifting rates of 2, 4, and $6 \%$ GSA were added to the optimum lime rate determined.

The strength index test and compaction tests were done according to the standard of [35], while the CBR was finished utilizing the [36] standard.

\section{Results and discussion}

\section{Preliminary and index results}

The rundown of the aftereffects of the preliminary and index properties tests for soil tests A, B, and C are shown in Table 3. The natural moisture content of the selected soil samples A, B, and C were 13.19, 2.45 , and $30.65 \%$, respectively, which showed that soil sample B had the least characteristic natural moisture content, and test $\mathrm{C}$ had the most elevated natural moisture content. Lambe and Whitman [37] expressed that the natural moisture of a soil relies to a great extent upon void proportion and specific gravity, which is, again to a great extent, influenced by climatic conditions such as temperature and intensity and term of precipitation in the region. The specific gravity of a soil sample is a proportion of the weight of the aggregate to the weight of an equivalent volume of water. The specific gravity of samples A, B, and C were 1.85, 2.77, and 2.77 separately. These were within the ranges given in [38] for clay minerals, Halloysite $(1.60$ - 2.55) and Biotite $(2.8$ - 3.2), which shows that the soil samples were halloysites. Das [39] expressed that most clay minerals have a specific gravity that falls in a general range $(1.6-2.9)$. In this manner, the soil samples are halloysites. 
The soil samples were ordered utilizing the AASHTO [40] soil classification framework; for granular materials having a place with A-2 class with critical constituent materials such as silty or clayey rock and sand with under $35 \%$ passing a $75 \mu \mathrm{m}$ sieve, the particle size investigation demonstrated estimations of 3.7, 4.4, and $3.9 \%$ passing the No. 200 sieve for samples A, B, and C, respectively.

The soil samples were additionally arranged by their liquid limit and plasticity index. Soil samples $\mathrm{A}$ and $\mathrm{C}$ were named $\mathrm{A}-2-7$, with liquid limit more noteworthy than $41 \%$ and plasticity index more prominent than $11 \%$, and sample B as A-2-5, with plasticity index of $8.59 \%$. As per the AASHTO [40] characterization, soils having a place with this class are viewed as acceptable subgrade material, dependent on these consistency limits; however, strength parameters are additionally required to guarantee they meet the design criteria as determined for various projects.

Table 3 Summary of properties of soil samples.

\begin{tabular}{cccc}
\hline Property & Sample A (IDITA) & $\begin{array}{c}\text { Sample B } \\
\text { (NTA) }\end{array}$ & $\begin{array}{c}\text { Sample C } \\
\text { (ETF) }\end{array}$ \\
\hline Percentage Passing & $3.7 \%$ & $4.4 \%$ & $3.9 \%$ \\
BS No 200 Sieve & $13.19 \%$ & $2.45 \%$ & $30.65 \%$ \\
Natural Moisture Content, \% & 1.85 & 2.77 & 2.17 \\
Specific Gravity & $\mathrm{A}-2-7$ & $\mathrm{~A}-2-5$ & $\mathrm{~A}-2-7$ \\
AASHTO Classification & 42.34 & 54.15 & 74.15 \\
Liquid Limit, \% & 20.50 & 45.57 & 51.61 \\
Plastic Limit, \% & 21.85 & 8.59 & 22.54 \\
Plasticity Index, \% & 1685 & 1599 & 1396 \\
Maximum Dry Density, $\mathrm{kg} / \mathrm{m}^{3}$ & 19.3 & 31.70 & 28.30 \\
Optimum Moisture Content, \% & 4.00 & 2.00 & 2.00 \\
California Bearing Ratio, \% & 60.43 & 19.19 & 30.62 \\
Triaxial Shear Strength, $\mathrm{kN} / \mathrm{m}^{2}$ & & & \\
\hline
\end{tabular}

Table 4 Summary of Atterberg limits for lime stabilization.

\begin{tabular}{ccccc}
\hline Sample & Lime Stabilization, $\%$ & $\begin{array}{c}\text { Liquid } \\
\text { Limit (LL), \% }\end{array}$ & $\begin{array}{c}\text { Plastic } \\
\text { Limit (PL), \% }\end{array}$ & $\begin{array}{c}\text { Plasticity } \\
\text { Index (PI), \% }\end{array}$ \\
\hline \multirow{3}{*}{ A } & 0 & 42.34 & 20.50 & 21.85 \\
& 4 & 34.85 & 25.73 & 9.12 \\
& 5 & 54.58 & 39.14 & 15.44 \\
6 & 40.95 & 24.58 & 16.37 \\
\hline \multirow{3}{*}{ B } & 0 & 54.15 & 45.57 & 8.59 \\
& 3 & 56.67 & 41.78 & 14.89 \\
& 4 & 34.00 & 23.37 & 10.62 \\
C & 6 & 59.47 & 44.52 & 14.94 \\
& 0 & 74.15 & 51.61 & 22.54 \\
& 4 & 64.98 & 44.88 & 20.10 \\
\end{tabular}

\section{Lime stabilization}

The Atterberg limits of the soil samples on the addition of changing rates of lime to decide the optimum lime measurements dependent on a decrease in plasticity index are given in Table 4. Figures 1 3 indicate the variety of Atterberg cutoff points, with lime dosage for soil samples A, B, and C, separately. The outcomes indicated a critical decrease in the liquid limit from 42.34 to $34.85 \%$, 
http://wjst.wu.ac.th

expansion in the plastic limit from 20.50 to $25.73 \%$, and diminished plasticity index from 21.85 to 9.12 $\%$ in addition of $4 \%$ lime, demonstrating a general improvement in the plasticity index of soil sample A. On addition of $5 \%$ lime, the liquid limit increased to $54.58 \%$, the plastic limit increased to $39.14 \%$, and a decrease in the plasticity index to $15.44 \%$, demonstrating low plasticity. The addition of $6 \%$ lime furthermore diminished the liquid limit to $40.95 \%$, plastic limit to $24.59 \%$, and plasticity index to 16.37 $\%$. According to Yoon et al. [41] a decrease in the plasticity index gives a sign of a progressively steady soil with checked expanded usefulness. Given the outcomes in Table 4, lime doses of $4 \%$, and $6 \%$ were chosen as the optimum doses for stabilizing soil samples $\mathrm{A}$ and $\mathrm{C}$, respectively. However, the addition of lime for test B brought about an expansion in the plasticity index. Lime adjustment is not prescribed for soils with PI $<10$. The acquired measurements were then used to determine the engineering properties of the stabilization samples before the addition of GSA.

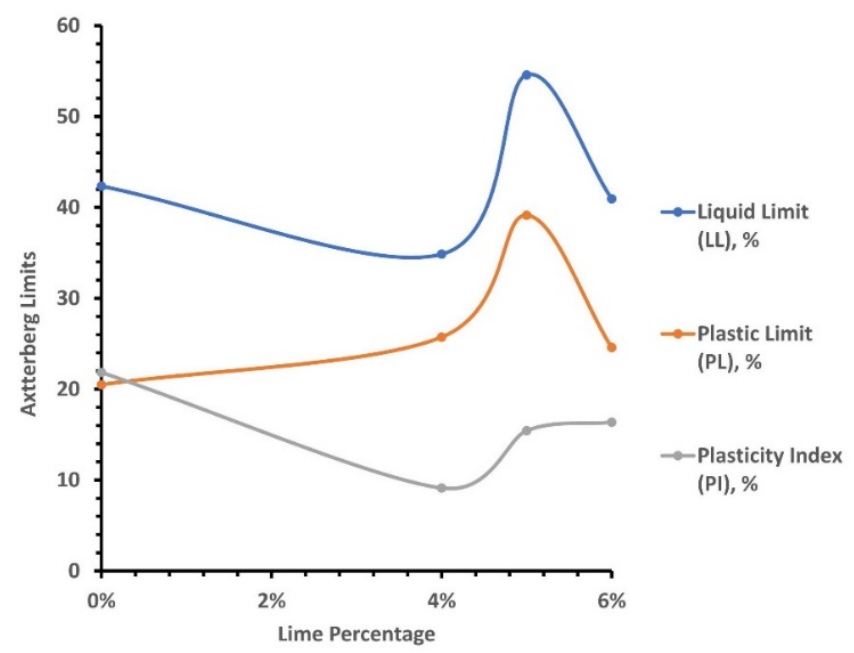

Figure 1 Variation of Atterberg limits with varying lime percentages for sample A.

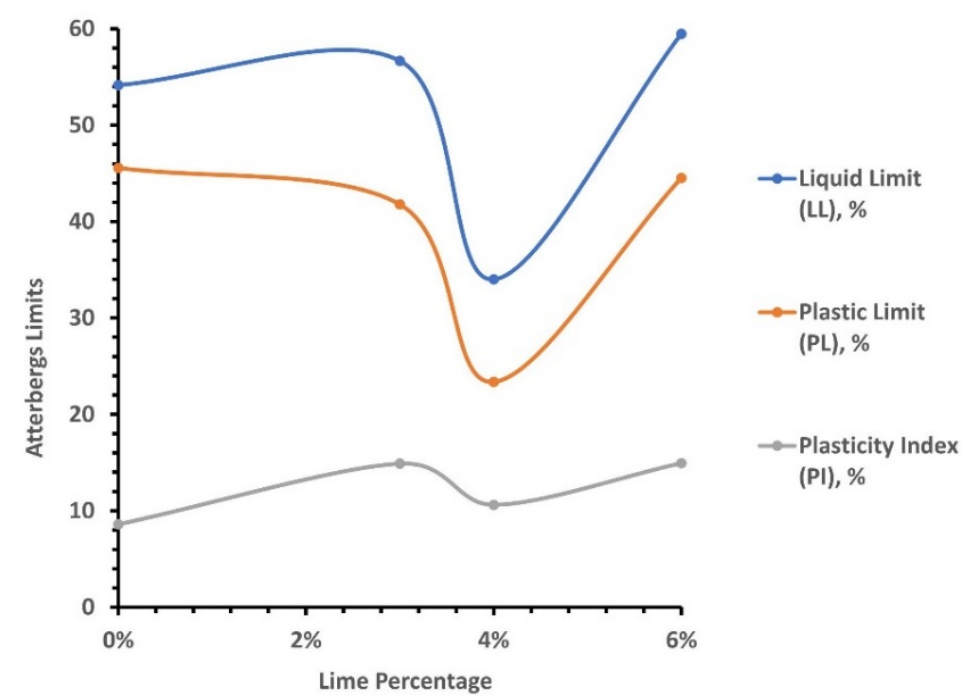

Figure 2 Variation of Atterberg limits with varying lime percentages for sample B. 


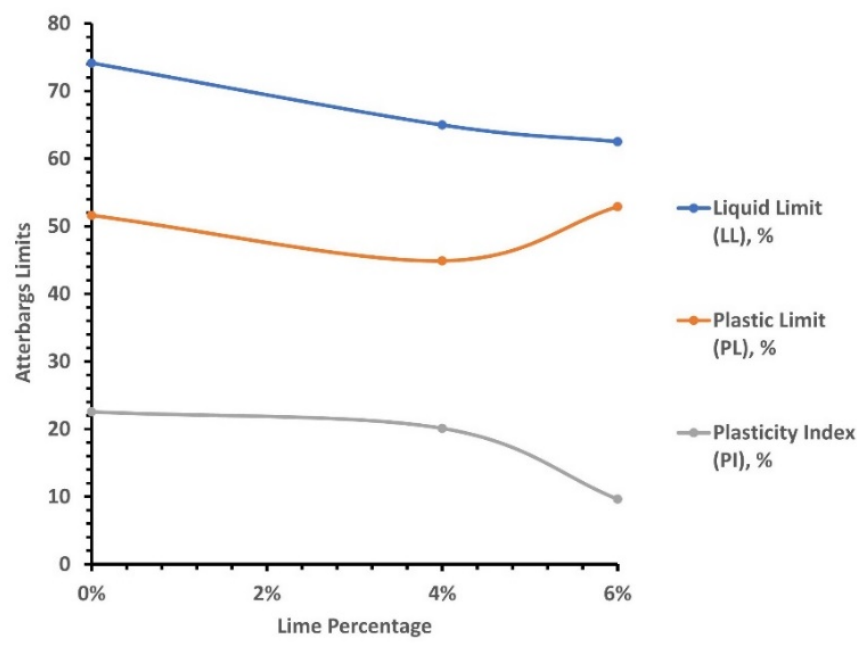

Figure 3 Variation of Atterberg limits with varying lime percentages for sample C.

\section{Groundnut shell ash used in the experiments}

Groundnut shell was sourced from nearby ranchers in the Ile-Ife area (Nigeria, South West Region). It was washed and liberated from any earth or contaminant. The shell was then dried outdoors for $72 \mathrm{~h}$. Ash was acquired by burning the shells at $600{ }^{\circ} \mathrm{C}$ for $24 \mathrm{~h}$ in an open drum to get the necessary GSA that was adequate for the investigation. The collected GSA was mixed carefully to get homogeneous material for spreading. The $\mathrm{pH}$ of the GSA used had an average $\mathrm{pH}$ of 9.25 (8.9 - 9.6) concentration. The chemical compositions of the GSA were analyzed in the laboratory to conduct environmental chemical analyses, as indicated by Ikumapayi [42]. The composition of GSA is presented in Table 5.

Table 5 Composition of GSA.

\begin{tabular}{ccccccccccccc}
\hline $\mathbf{C a O}$ & $\mathbf{F e}_{\mathbf{2}} \mathbf{O}_{\mathbf{3}}$ & $\mathbf{M g O}$ & $\mathbf{S i O}_{\mathbf{2}}$ & $\mathbf{A l}_{\mathbf{2}} \mathbf{O}_{\mathbf{3}}$ & $\mathbf{K}_{\mathbf{2}} \mathbf{O}$ & $\mathbf{N a}_{\mathbf{2}} \mathbf{O}$ & $\mathbf{S O}_{3}$ & $\mathbf{C O}_{3}$ & $\mathbf{H C O}_{3}$ & $\mathbf{T i O}_{\mathbf{2}}$ & $\mathbf{P}_{\mathbf{2}} \mathrm{O}_{\mathbf{5}}$ & $\mathbf{L O I}$ \\
\hline 5.91 & 9.12 & 5.72 & 41.36 & 13.15 & 3.18 & 9.11 & 6.21 & 6.02 & 8.20 & 2.11 & 6.12 & 3.61 \\
\hline
\end{tabular}

Note: * All oxides are in percentage. LOI*-loss on ignition.

\section{Compaction test}

The compaction test was done to decide the optimum moisture content (OMC) and the maximum dry density (MDD) of the 3 soil samples at their natural states, when stabilized with optimum lime doses, and when GSA was added. The outcome shows that the natural soil samples had OMCs of 19.3, 31.7, and $28.3 \%$, and MDDs of 1,685, 1,599, and $1,396 \mathrm{~kg} / \mathrm{m}^{3}$ for samples A, B, and C, respectively. For sample A, stabilization with $4 \%$ lime diminished the OMC to $17.8 \%$ and diminished the MDD to $1,590 \mathrm{~kg} / \mathrm{m}^{3}$. For sample C, stabilization with $6 \%$ lime expanded the OMC to $31.7 \%$ and decreased the MDD to 1,270 $\mathrm{kg} / \mathrm{m}^{3}$. [37] expressed that, for good soil, the lower the OMC, the better its workability, and that an expansion in dry density is a pointer of progress. The expansion in OMC with the addition of lime can be ascribed to expanding interest for water by different cations and the clay mineral particles to experience hydration response [43-45]. The decline in the OMC for sample A might have been because of the cation exchange reaction that caused a flocculation of the clay molecule.

The diminishing in the MDD could be credited to the substitution of the soil by the lime particles which had lower specific gravity contrasted with that of the soil $[43,45,46]$. It might likewise be ascribed to covering the soil by the ash content, which resulted in enormous particles with bigger voids, and 
consequently, less density [47,48]. For soil sample A, the addition of $2 \%$ GSA and $4 \%$ lime to the soil brought about a diminishing in the MDD to $1,435 \mathrm{~kg} / \mathrm{m}^{3}$ and increment in OMC to $23.2 \%$, and the addition of $4 \%$ GSA and $4 \%$ lime diminished the MDD to $1,385 \mathrm{~kg} / \mathrm{m}^{3}$ and expanded the OMC to 24.0 $\%$. Addition of $6 \%$ GSA and $4 \%$ lime decreased the MDD further to $1,350 \mathrm{~kg} / \mathrm{m}^{3}$ and an expanded OMC of $27.3 \%$. For sample B, the addition of $2 \%$ GSA lime to the soil brought about a decline in the MDD to $1,325 \mathrm{~kg} / \mathrm{m}^{3}$ and decreased the OMC to $29.9 \%$, and the addition of $4 \%$ GSA diminished the MDD to $1,318 \mathrm{~kg} / \mathrm{m}^{3}$ and diminished the OMC to $28.9 \%$. A blend of $6 \%$ GSA diminished the MDD to 1,239 $\mathrm{kg} / \mathrm{m}^{3}$ and an expanded the OMC to $35.5 \%$. For sample $\mathrm{C}$, the addition of $2 \%$ GSA and $6 \%$ lime to the soil brought about a diminishing of the MDD to $1,282 \mathrm{~kg} / \mathrm{m}^{3}$ and an expansion in the OMC to $31.81 \%$. The addition of $4 \%$ GSA and $6 \%$ lime expanded the MDD to $1,213 \mathrm{~kg} / \mathrm{m}^{3}$ and expanded the OMC to $33.7 \%$. A blend of $6 \%$ GSA and $6 \%$ lime expanded the MDD to $1,233 \mathrm{~kg} / \mathrm{m}^{3}$ and expanded the OMC to $35.21 \%$.

The expansion in the OMC affirms the pozzolanic conduct of GSA, with an expanding interest for water to respond and form aggregate particles in the soil. Table 6 shows the consequence of MDD and OMC of the variation in blend level of GSA at optimum lime measurements.

Table 6 Summary of compaction test on lime stabilized samples and varying GSA.

\begin{tabular}{cccc}
\hline Samples & $\begin{array}{c}\text { Percentage } \\
\text { Stabilization }\end{array}$ & $\begin{array}{c}\text { Optimum Moisture } \\
\text { Content } \mathbf{( \% )}\end{array}$ & $\begin{array}{c}\text { Maximum Dry } \\
\text { Density }\left(\mathbf{k g} / \mathbf{m}^{\mathbf{3}}\right)\end{array}$ \\
\hline \multirow{3}{*}{$\mathrm{A}$} & $0 \% \mathrm{GSA}$ & 17.80 & 1,590 \\
& $2 \% \mathrm{GSA}$ & 23.20 & 1,435 \\
& $4 \% \mathrm{GSA}$ & 24.00 & 1,385 \\
& $6 \% \mathrm{GSA}$ & 27.30 & 1,350 \\
\hline \multirow{2}{*}{$\mathrm{B}$} & $0 \% \mathrm{GSA}$ & 31.70 & 1,512 \\
& $2 \% \mathrm{GSA}$ & 29.90 & 1,325 \\
& $4 \% \mathrm{GSA}$ & 28.90 & 1,318 \\
& $6 \% \mathrm{GSA}$ & 33.50 & 1,239 \\
\hline & $0 \% \mathrm{GSA}$ & 31.70 & 1,270 \\
& $2 \% \mathrm{GSA}$ & 31.81 & 1,282 \\
& $4 \% \mathrm{GSA}$ & 33.70 & 1,213 \\
& $6 \% \mathrm{GSA}$ & 35.21 & 1,233 \\
\hline
\end{tabular}

The effects of the addition of varying quantities of GSA content at the optimum lime dosage on OMC and MDD are illustrated in Figures $\mathbf{4}$ and 5, respectively. Generally, contraction in the MDD occurred when increasing the GSA content to $6 \%$ by weight. The correlation coefficients obtained for $\%$ GSA content and maximum dry density were $0.94,0.92$, and 0.72 , respectively, for soil samples A, B, and $\mathrm{C}$. These results indicated a very strong positive correlation obtained for all the soil samples. 


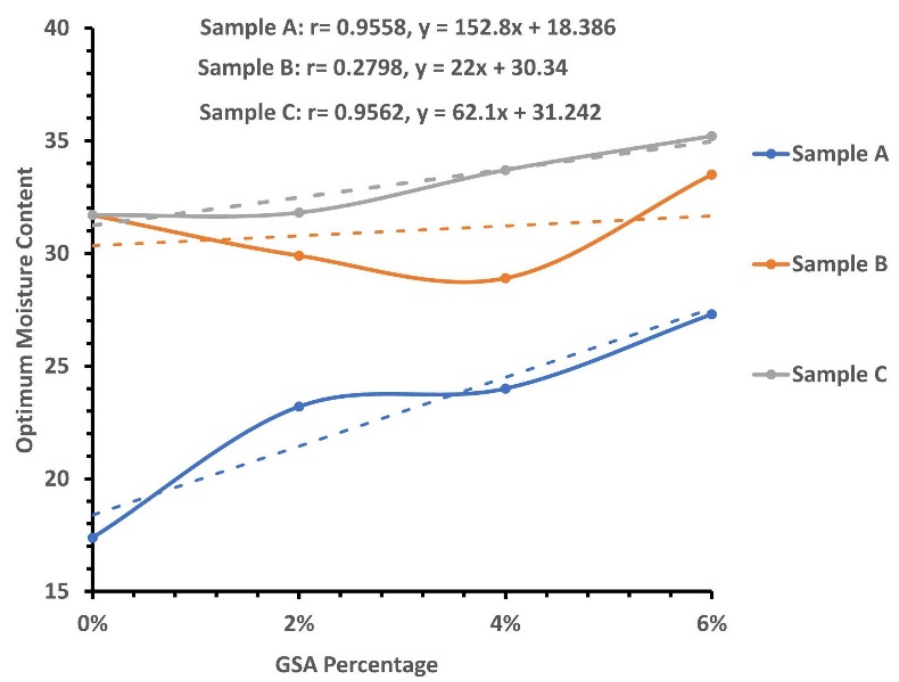

Figure 4 Variation of OMC with increasing GSA at optimum lime dosage.

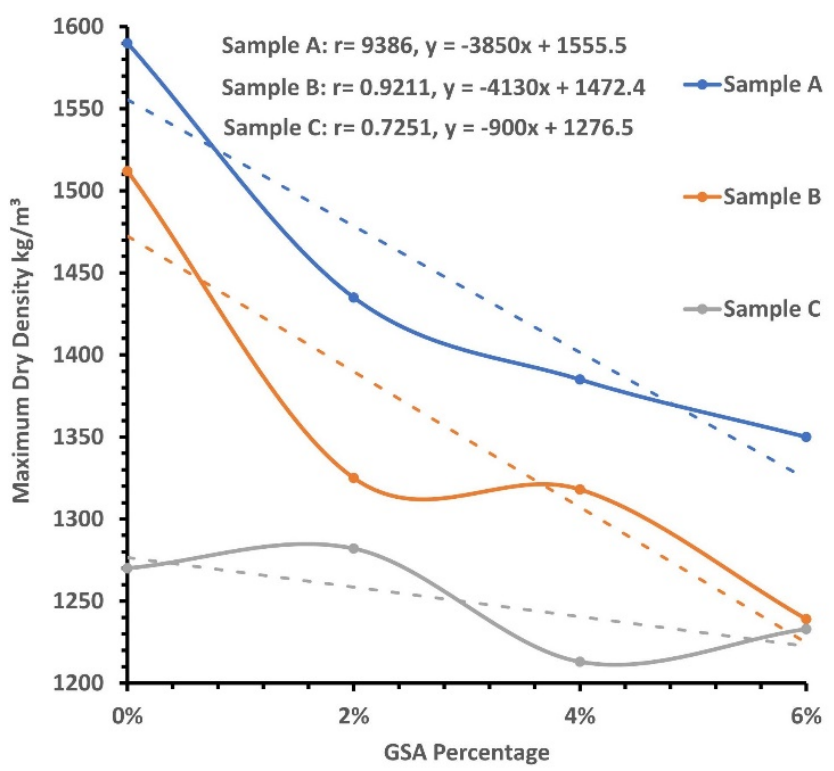

Figure 5 Variation of maximum dry density with increasing GSA at optimum lime dosage.

\section{California Bearing Ratio}

In highway structural works, it is significant to assess the quality of subgrade, subbase, and base course materials after compaction. The California Bearing Ratio (CBR) is an in-situ test (Figure 6) ordinarily used to gauge the strength of a soil layer by looking at the penetration resistance of the soil to that of a standard material. The CBR test is directed at the OMC of the soil, soil-lime or soil, and limeGSA, as determined from the compaction test. The California Bearing Proportion (CBR) esteems of the stabilized soils is a significant parameter in measuring the appropriateness of the stabilized soils. Thus, it 
indicates the strength and bearing capacity of the soil, which will help designers in recommending or dismissing the appropriateness of the soil as a base or sub-base material.

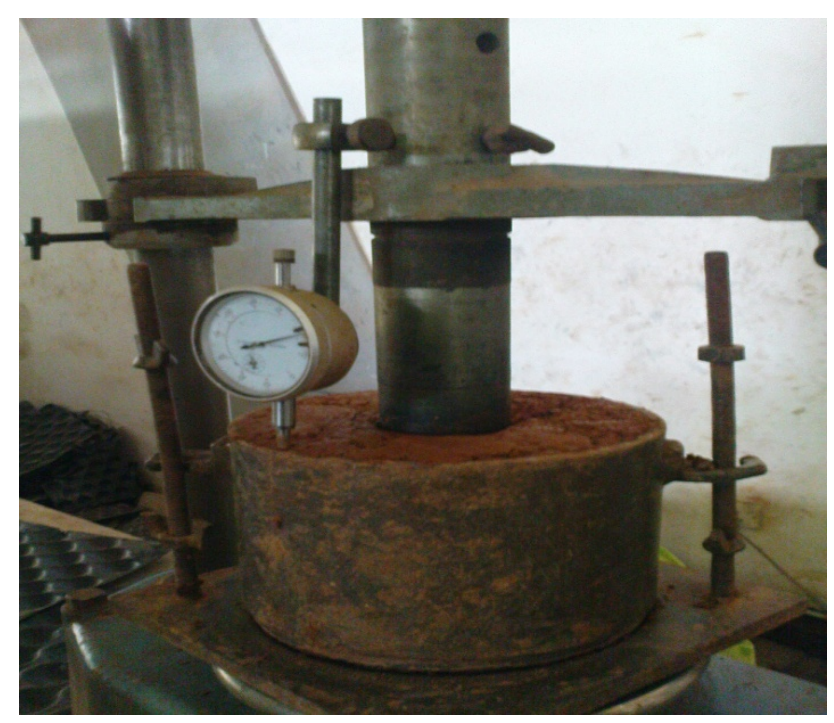

Figure 6 CBR test.

The unsoaked CBR esteems for the natural soil was seen at $4 \%$ for sample A, and $2 \%$ for both samples B and C. The low CBR and noteworthy lessening in the CBR estimations of the soil with the addition of lime can be ascribed to the high water content used during compaction. Additionally, the stabilization of soil with lime necessitates that the blend is permitted to cure for a couple of days before compacting. During curing, it is seen that the blend loses moisture and, thus, expansions in strength. The increase in strength of stabilized soil with increasing curing days proposes that the blend be permitted to cure so as to evaluate the genuine strength of the soil [49]. The results of the influence of addition of varying quantities of GSA content by weight is displayed in Table 7; the addition of 2, 4, and $6 \%$ GSA expanded the unsoaked CBR esteems to 8,6 , and $5 \%$ of soil-lime sample A; 5, 4, and $5 \%$ of soil-lime sample B; and 5, 10, and $5 \%$ for soil-lime sample $\mathrm{C}$. This shows that GSA can build the strength properties of soil, particularly with lime present, to improve the response between the soil and the additive.

The connection between GSA content at an optimum lime dosage and the unsoaked CBR is displayed in Figure 7. Very strong positive and strong positive correlations of $0.8,0.73$, and 0.47 were obtained respectively for the soil samples A, B, and C. 
Table 7 Summary of unsoaked CBR values for varying GSA at optimum lime.

\begin{tabular}{ccc}
\hline Samples & Percentage Stabilization & Unsoaked CBR Values (\%) \\
\hline & $0 \%$ GSA & 7 \\
$\mathrm{~A}$ & $2 \% \mathrm{GSA}$ & 8 \\
& $4 \% \mathrm{GSA}$ & 6 \\
& $6 \% \mathrm{GSA}$ & 5 \\
\hline $\mathrm{B}$ & $0 \% \mathrm{GSA}$ & 2 \\
& $2 \% \mathrm{GSA}$ & 5 \\
& $4 \% \mathrm{GSA}$ & 4 \\
$\mathrm{C}$ & $6 \% \mathrm{GSA}$ & 5 \\
& $0 \% \mathrm{GSA}$ & 3 \\
& $2 \% \mathrm{GSA}$ & 5 \\
& $4 \% \mathrm{GSA}$ & 10 \\
\hline
\end{tabular}

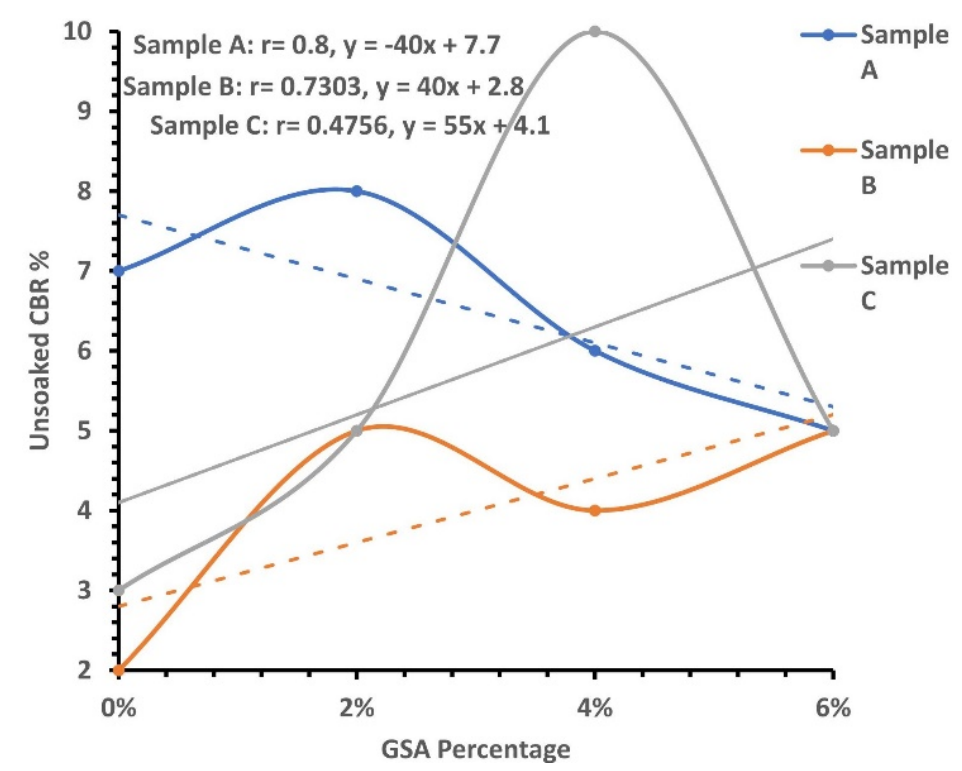

Figure 7 Variation of unsoaked CBR values at optimum lime.

\section{Undrained triaxial shear strength test}

The triaxial test is one of the most dependable techniques accessible for the assurance of shear parameters; an expansion in the shear strength of a soil demonstrates an improvement in the strength of the soil, and an improvement in construction functionality [50]. The synopsis of the outcomes of the triaxial test on un-stabilized and lime-stabilized samples is shown in Table 8. The test was performed from soil samples acquired from the remolded soil, with the OMC obtained from the compaction test. Cell pressures of 20,40 , and $80 \mathrm{kN} / \mathrm{m}^{2}$ were applied. The shear strength of the soil samples was 60.43 , 19.19 , and $30.62 \mathrm{kN} / \mathrm{m}^{2}$, respectively, for un-stabilized samples A, B, and C. The addition of $4 \%$ lime and $6 \%$ lime expanded the shear strength to 188.36 and $44.21 \mathrm{kN} / \mathrm{m}^{2}$ for sample A. The shear strength showed a significant increase in sample B from $19.19 \mathrm{kN} / \mathrm{m}^{2}$ soil-lime to $201.48 \mathrm{kN} / \mathrm{m}^{2}$ at $2 \%$ GSA and to $47.52 \mathrm{kN} / \mathrm{m}^{2}$ at $4 \% \mathrm{GSA}$. Increase in shear strength qualities were also observed in soil sample $\mathrm{C}$ from 
http://wjst.wu.ac.th

$30.62 \mathrm{kN} / \mathrm{m}^{2}$ soil-lime to $111.65 \mathrm{kN} / \mathrm{m}^{2}$ at $4 \% \mathrm{GSA}$ content, and $58.80 \mathrm{kN} / \mathrm{m}^{2}$ at $6 \% \mathrm{GSA}$ content. The expansion in shear strength further affirms the improvement prior shown in the geotechnical properties of lateritic soil with the addition of GSA. An expansion in the shear quality of a soil exhibits an improvement in the quality of the soil and, furthermore, an improvement in strength functionality [51].

Table 8 Variation of shear strength with GSA addition at optimum lime.

\begin{tabular}{|c|c|c|c|c|c|}
\hline Sample & $\begin{array}{c}\text { Percentage } \\
\text { Ash }\end{array}$ & $\begin{array}{c}\text { Cohesion, } \\
\text { Friction C } \\
\left(\mathbf{k N} / \mathbf{m}^{2}\right)\end{array}$ & $\begin{array}{c}\text { Internal } \\
\text { Angle }(\phi)\end{array}$ & $\begin{array}{c}\text { Average } \\
\text { Deviator Stress } \\
\left(\sigma_{1}-\sigma_{3}\right)\end{array}$ & $\begin{array}{c}\text { Shear Stress } \\
=C+\left(\sigma_{1}-\sigma_{3}\right) \\
\tan \phi\left(\mathbf{k N} / \mathbf{m}^{2}\right)\end{array}$ \\
\hline \multirow{4}{*}{ A } & $0 \%$ GSA & 46.36 & 9 & 88.86 & 60.43 \\
\hline & $2 \%$ GSA & 18.28 & 27 & 135.56 & 86.79 \\
\hline & $4 \%$ GSA & 112.73 & 14 & 303.33 & 188.36 \\
\hline & $6 \%$ GSA & 40.90 & 2 & 94.85 & 44.21 \\
\hline \multirow{4}{*}{$\mathrm{B}$} & $0 \%$ GSA & 16.71 & 4 & 35.47 & 19.19 \\
\hline & $2 \%$ GSA & 45.12 & 35 & 223.31 & 201.48 \\
\hline & $4 \%$ GSA & 22.85 & 16 & 86.04 & 47.52 \\
\hline & $6 \%$ GSA & 35.79 & 28 & 182.70 & 46.56 \\
\hline \multirow{4}{*}{$\mathrm{C}$} & $0 \%$ GSA & 16.37 & 14 & 57.16 & 30.62 \\
\hline & $2 \%$ GSA & 45.77 & 17 & 161.62 & 91.38 \\
\hline & $4 \%$ GSA & 28.13 & 24 & 187.58 & 111.65 \\
\hline & $6 \%$ GSA & 23.76 & 20 & 96.28 & 58.80 \\
\hline
\end{tabular}

Correlation coefficients of $0.10,0.11$, and 0.38 were obtained for samples $\mathrm{A}, \mathrm{B}$, and $\mathrm{C}$, respectively, between GSA contents at an optimum lime dosage and the shear strength of the soil samples, as shown in Figure 8.

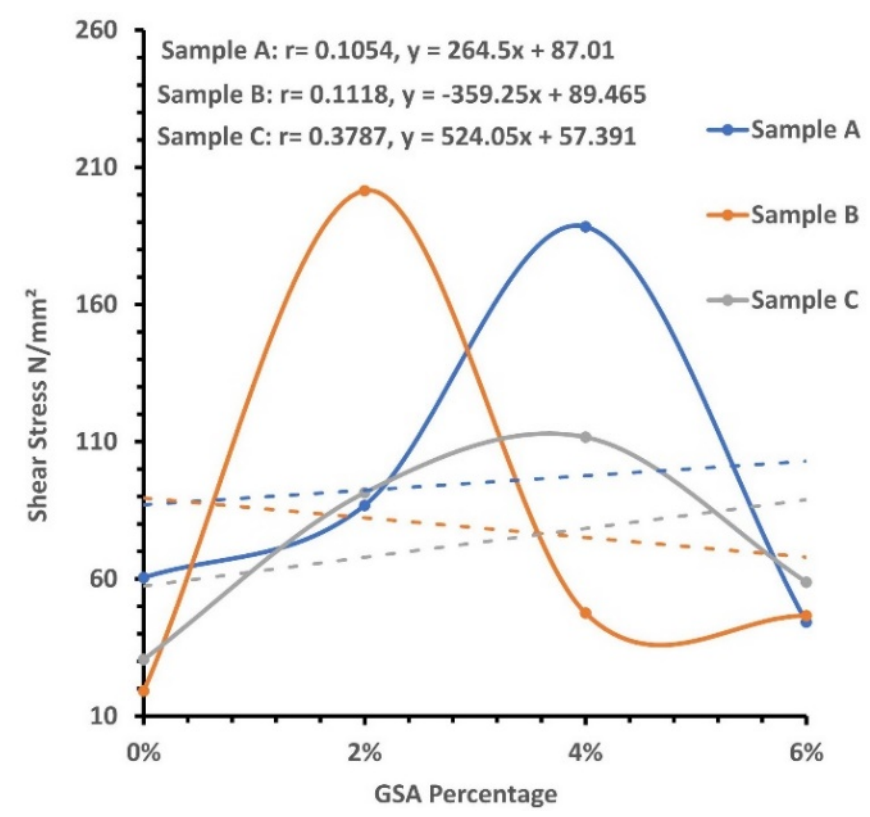

Figure 8 Influence of GSA content at optimum lime dosage on soil shear stress. 
http://wjst.wu.ac.th

\section{Conclusions}

Stabilization of lime lateritic soil with GSA improved the nature of the lateritic soil by altogether decreasing the plasticity index, plastic limit, and liquid limit of the soil samples.

The maximum dry density of soil samples A, B, and C diminished significantly with the addition of lime and GSA, with the most elevated worth acquired at $4 \%$ lime and $2 \%$ GSA for sample A, $0 \%$ lime and $2 \%$ GSA for sample B, and $6 \%$ lime and $2 \%$ GSA for sample $\mathrm{C}$. The OMC expanded extensively for the samples $\mathrm{A}$ and $\mathrm{C}$ but lessened at the addition of GSA content for sample B until $6 \%$ GSA. The CBR esteems for the un-stabilized subsoil tests were likewise expanded. The addition of GSA expanded the CBR esteems for the lime-stabilized samples A, B, and C. This indicates that GSA has an improving, strengthening impact on the proportion of CBR values. The addition of $4 \%$ GSA content in all the soil samples expanded the shear stress of all the soil samples.

In summary, GSA improves the properties of soil, in that it helps in shaping colloidal particles and decreases the inclination of the soil to expand when wet; the optimum percentage of GSA content addition to lime-stabilized structural lateritic soil is at $4 \%$. The outcome of this research will serve as a guide for construction workers, engineers, and other researchers on the performance of GSA on limestabilized structural lateritic in soil stabilization towards the design and construction of sustainable structural works.

\section{References}

[1] MM Rahman and SL Gassman. Effect of resilient modulus of undisturbed subgrade soils on pavement rutting. Int. J. Geotech. Eng. 2019; 13, 152-61.

[2] E Mukiza, L Zhang, X Liu and N Zhang. Utilization of red mud in road base and subgrade materials: A review. Resour. Conserv. Recy. 2019; 141, 187-99.

[3] SA Ola, B Ogunmokun-Akinmolu, OO Ojuri and OE Oluwatuyi. Estimating road pavement failure susceptibility using a modified TDRAMS model in South-Western Nigeria. Int. J. Eng. Res. Afr. 2018; 40, 63-77.

[4] AM Neville. Properties of concrete. $4^{\text {th }}$ ed. Pearson Education Asia, Malaysia, 2000.

[5] RK Etim, AO Eberemu and KJ Osinubi. Stabilization of black cotton soil with lime and iron ore tailings admixture. Transp. Geotech. 2017; 10, 85-95.

[6] AA Sharo, Y Alhowaidi and MS Al-Tawaha. Feasibility of calcium chloride dehydrate as stabilizing agent for expansive soil. J. Eng. Sci. Tech. Rev. 2018; 11, 156-61.

[7] TS Amhadi and GJ Assaf. Assessment of strength development of cemented desert soil. Int. J. LowCarbon Technol. 2019; 14, 543-49.

[8] S Hesami, A Modarres, M Soltaninejad and H Madani. Mechanical properties of roller compacted concrete pavement containing coal waste and limestone powder as partial replacements of cement. Const. Build. Mater. 2016; 111, 625-36.

[9] AA Elbaz, AM Aboulfotoh, AM Dohdoh and AM Wahba. Review of beneficial uses of cement kiln dust, fly ash and their mixture. J. Mater. Environ. Sci. 2019; 10, 1062-73.

[10] G Norhaiza, M Khairunisa and WA Saffuan. Utilization of fly ash in construction. IOP Conf. Ser. Mater. Sci. Eng. 2019; 601, 012023.

[11] MB Vabi, HA Ajeigbe, AA Kasim, SA Sadiq and L Bala. Adoption of varietal and accompanying groundnut technologies in Sokoto and Kebbi States of Northwestern Nigeria. Net J. Agric. Sci. 2019; 7, 56-68.

[12] NN Thant. Effect of lime on engineering properties of cohesive soil. Int. J. Trend Sci. Res. Dev. $2018 ; 2,1757-62$.

[13] A Gupta, VK Arora and S Biswas. Contaminated dredged soil stabilization using cement and bottom ash for use as highway subgrade fill. Int. J. Geotech. Eng. 2017; 8, 20.

[14] F Bertoldo and L Callisto. Delayed response of excavations in structured clays. Can. Geo. J. 2019; 56, 1584-95.

[15] R Lal. Soil management in the developing countries. Soil Sci. 2000; 165, 57-72. 
http://wjst.wu.ac.th

[16] CA Oyelami and JLV Rooy. A review of the use of lateritic soils in the construction/development of sustainable housing in Africa: A geological perspective. J. Afr. Earth Sci. 2016; 119, 226-37.

[17] FU Ogbuagu and CAU Okeke. Geotechnical properties of lateritic soil from Nimo and Nteje areas of Anambra State, Southeastern Nigeria. IOP Conf. Ser. Mater. Sci. Eng. 2019; 640, 012078.

[18] FH Chen. Foundations on expansive soils. Elsevier Scientific Pubublication, Amsterdam, 1975.

[19] KW Warren and TM Kirby. Expansive clay soils a wide spread and costly geohazard. GI Amer. Soc. Civ. Eng. 2004; 5, 24-28.

[20] AA Moataz, MA Ibrahim and HA Abdulrahman. Effect of swelling on the shear strength behaviour of expansive soil. Int. J. Geotech. Eng. 2021. https://doi.org/10.1080/19386362.2019.1651043.

[21] F Salour and S Erlingsson. Resilient modulus modelling of unsaturated subgrade soils: Laboratory investigation of silty sand subgrade. Road Mater. Pavement Des. 2015; 16, 553-68.

[22] C Liu and J Evett. Soils and foundations. $8^{\text {th }}$ ed. Pearson-Prentice Hall, Upper Saddle River, New Jersey, 2013, p. 201-16.

[23] NK Sharma, SK Swain and UC Sahoo. Stabilization of a clayey soil with fly ash and lime: A micro level investigation. Geotech. Geol. Eng. 2012; 30, 1197-205.

[24] N Nalluri and VR Karri. Use of groundnut shell compost as a natural fertilizer for the cultivation of vegetable plants. Int. J. Adv. Res. Sci. Eng. 2018; 7, 97-104.

[25] R Jambunathan. Groundnut quality characteristics. Uses of tropical grain legumes. In: Proceedings of the Consultants Meeting. ICRISAT Centre, India, 1991.

[26] GB Nyior, SA Aye and SE Tile. Study of mechanical properties of raffia palm fibre/groundnut shell reinforced epoxy hybrid composites. J. Min. Mater. Character. Eng. 2018; 6, 179-92.

[27] BA Alabadan, CF Njoku and MO Yusuf. The potentials of groundnut shell ash as concrete admixture. Agric. Eng. Int. CIGR J. 2006; 8, 1-8.

[28] TS Amhadi and GJ Assaf. Assessment of strength development of cemented desert soil. Int. J. LowCarbon Technol. 2019; 14, 543-49.

[29] S Dhar and M Hussain. The strength and microstructural behavior of lime stabilized subgrade soil in road construction. Int. J. Geotech. Eng. 2021; 15, 471-83.

[30] P Akula and DN Little. Analytical tests to evaluate pozzolanic reaction in lime stabilized soils. MethodsX 2020; 7, 100928.

[31] II Obianyo, AP Onwualu and ABO Soboyejo. Mechanical behaviour of lateritic soil stabilized with bone ash and hydrated lime for sustainable building applications. Const. Mater. 2020; 12, e00331.

[32] BS 1377-1. Methods of test for soils for Civil Engineering purposes. General requirements and sample preparation. British Standards, 2016.

[33] ASTM D422-63. Standard test method for particle-size analysis of soils. American Society for Testing and Materials, 2007.

[34] ASTM D4318. Standard test methods for liquid limit, plastic limit, and plasticity index of soils. American Society for Testing and Materials, 2000.

[35] ASTM D698. Standard test method for laboratory compaction characteristics of soil using standard effort. American Society for Testing and Materials, 2012.

[36] ASTM D1883. Standard test method for CBR (California bearing ratio) of laboratory compacted soils. American Society for Testing and Materials, 1999.

[37] TW Lambe and RV Whitman. Soil mechanics. SI Version, John Wiley \& Sons, 1979, p. 112-25.

[38] F Guo, S Aryana, Y Han and Y Jiao. A review of the synthesis and applications of polymernanoclay composites. Appl. Sci. 2018; 8, 1696.

[39] BM Das. Advanced soil mechanics. $5^{\text {th }}$ ed. CRC Press, New York, Emmanuel, Visual Inspection of Concrete, 2019, p. 355-63.

[40] AASHTO. The AASHTO guide for design of pavement structures. American Association of State Highway and Transportation Officials, Washington, D.C, 1993.

[41] TC Yoon, NZM Yunus, A Marto, MA Hezmi, SN Jusoh and K Ahmad. Comparison of soil index properties value for different pre-drying conditions on clayey soil. UTM Jurnal Teknologi 2015; 2, 23-30. 
[42] CM. Ikumapayi. Properties of groundnut shell (Arachis hypogaea) ash blended portland cement. $J$. Appl. Sci. Environ. Manage. 2018; 22, 1553-56.

[43] G Moses. Stabilization of black cotton soil with ordinary portland cement using bagasse ash as admixture. IRJI J. R. Eng. 2008; 5, 107-15.

[44] OA Adetayo, OO Amu and AO Ilori. Cement stabilized structural foundation lateritic soil with bone ash powder as additive. Arid Zone J. Eng. Technol. Environ. 2019; 15, 479-87.

[45] KJ Osinubi and TA Stephen. Effect of curing period on bagasse ash stabilized black cotton soil. In: Proceedings of the Bi-monthly Meetings/Workshop, Material Society of Nigeria, Zaria. 2006, p. 18.

[46] KJ Osinubi. Influence of compactive efforts and compaction delays on lime-treated soils. J. Trans. Eng. 1998; 124, 149-55.

[47] TY Elkady and AA Shaker. Role of cementation and suction in the swelling behavior of limetreated expansive soils. J. Mater. Civ. Eng. 2018; 30, 04018073.

[48] SA Ola. The geotechnical properties of black cotton soils of North Eastern Nigeria. Tropical Soils of Nigeria in Engineering Practice, 1983, p. 155-71.

[49] JN Jha and KS Gill. Effect of rice husk ash on lime stabilization. J. Inst. Eng. India. 2006; 87, 33-9.

[50] BM Das. Principles of geotechnical engineering. $7^{\text {th }}$ ed. PWS Publishing Company, 2006, p. 45360 .

[51] AO Ibrahim and PO Falae. Integrated geophysical and geotechnical methods for pre-foundation investigations. J. Geol. Geophys. 2018; 8, 1-9. 